\title{
SUBSTANTIATION OF OPTIMAL PARAMETERS OF THE MAN-MADE DEPOSITS
}

\author{
Peregudov V.V. \\ professor, Doctor in technical science, director, \\ $\mathrm{SE} \ll \mathrm{SDI}$ «Krivbassproekt»
}

Hryhoriev I.J.

Associate prof., Ph.D. in technical science, deputy director, $\mathrm{SE} « \mathrm{SDI}$ «Krivbassproekt»

\author{
Hryhoriev Y.I. \\ Ph.D. in technical science, senior lecturer, Kryvyi Rih National \\ University
}

The aim: The current states of open mining works at domestic enterprises, as well as the situation in the market of mineral resources require the search for new approaches to open mining works. This approach is a comprehensive development of mineral resources, which contributes to the improvement of technical and economic performance indicators for the mining enterprises. Purposeful formation of manmade deposits with the necessary parameters and their further development is one of the main directions of complex development, and the definition of these parameters and the study of their relationships is the scientific task of this publication.

Methods: The methods of patent search, analysis of literary sources were used to study the technology of formation and development man-made deposit, regression analysis and mathematical modeling of the main parameters of man-made deposits.

Object of research: man-made deposits of bulk type

Subject of research: the relationship of the parameters of man-made deposits

Scientific novelty. The dependences of the optimum values of the capacity and production capacity of the man-made deposit, which provide the best technical and economic indicators of the formation and development of the man-made deposit, are investigated in the work. It is proved that the specific cost of formation and development of man-made deposit are directly dependent on its capacity and inverse - on the production capacity. It was found that the capacity of the man-made deposit has a greater influence on the specific cost of formation and development of the man-made deposit, than its production capacity. Mathematical modeling of the main parameters of the man-made deposit was performed.

Practical significance. The results of studies of the main parameters of manmade deposits can be used by design organizations and mining enterprises in the design. Mathematical dependencies will allow to determine more fundamentally the main parameters of man-made deposit and will increase the accuracy of technical decisions of design institutes.

Keywords: man-made deposit, cost, capacity of man-made deposit, production capacity of man-made deposit, mathematical model, regression analysis. 


\section{Introduction}

The urgency of the problem. As a result of the activities of the mining and development industries, billions of cubic meters of waste in the form of overburden, sludge, slag, ash, etc., have accumulated on the planet's surface, which exacerbates the environmental burden, and therefore the problem of their utilization is of global importance. At the same time, Ukraine has a strong mining industry and ranks seventh in the world in terms of mineral production, so the problem of waste disposal is of the first importance for Ukraine. More than 2 billion tonnes of rock mass is mined annually from the Ukrainian subsoil, $60-70 \%$ of which is stored in stock dumps. However, the level of utilization of production waste reaches only $12-15 \%$, while in the advanced countries of the world it reaches $80 \%$. The tendency for the use of secondary resources is observed in the USA, Japan, Canada, Great Britain, France, Germany, South Africa and other industrialized countries.

For the Kryvyi Rih iron ore basin, which is one of the largest mining regions in the world, the problem of integrated deposits development and involvement in the recycling mining wastes is becoming increasingly important.

According to various estimates, the dumps and tailings ponds of KryvyiRih mining and processing plants contain up to 13 billion tonnes of overburden and up to 6 billion tonnes of waste of poor iron ore, at the same time the annual economic damage from environmental pollution is estimated at $300 \mathrm{mln}$ dollars. Therefore, it is possible to state with certainty that there is a substantial raw material base of secondary mineral resources $[1,2]$.

At the same time, the prospect of development of mining is characterized by an increase in the output of minerals with a constant decrease in their quality and complication of the conditions of exploitation of natural deposits. Therefore, in future, deposits of low quality ores, comparable to those of man-made deposits, will be involved in the development. Therefore, undoubtedly, the accumulated mining wastes, which may be man-made deposits, will eventually become one of the important sources of mineral resources.

However, as a result of unsystematic storage of mineral resources, the costs of further development of these mineral objects are significantly increased, as the work scope on re-excavation of the rock mass 
for the rocks output of the required type increases. In most cases, the development of mineral objects thus formed is associated with large quantitative and qualitative losses, and therefore, in most cases, their exploitation becomes economically impractical.

The aim. Investigate the dependencies and optimize the parameters of the man-made deposit of the bulk type, which would ensure the maximum efficiency of its development.

Scientific tasks. 1. to carry out an analysis of the theory and practice of formation and development of the man-made deposit in conditions of complex development of subsoil;

2. determine the main parameters of the man-made deposit, which have the greatest impact on the economic factors of technological processes;

3. identify the relationship between the main parameters of the man-made deposit, develop a mathematical model and optimize the parameters.

\section{Analysis of research in the formation of man-made deposits}

Taking into account external and internal factors in the works [1$3]$, the authors proposed different technologies of formation and development of man-made deposits, each of which is characterized by different advantages and disadvantages. At the same time, the technical and economic indicators of man-made deposit development will largely depend on the main parameters of the man-made deposit. The first difficulty in this aspect is the lack of a common approach to the list of the main parameters of the man-made deposit.

Secondly, the rational values of the main parameters of the manmade deposit will be determined by a combination of several factors: the cost of land acquisition, the method of formation of the man-made deposit, the equipment, the development system and the physical and mechanical properties of the man-made raw materials.

In the works [3-6] the problem of complex development of the man-made deposits is investigated, the basic terms and concepts are laid, the ways of formation of the man-made deposits are proposed. A number of schemes of selective storage of temporarily off-grade minerals have been found [6]. In addition, methodological principles of purposeful formation of the man-made deposits with specified parameters have been identified [7], which can be reduced to the following regulations: 
1. independent storage and development of temporary substandard ores and associated minerals in space and time (according to the regime of mining works in the open pit and market conditions);

2. minimum areas of alienated land;

3. minimum volumes of over-excavation in the development of the man-made deposit and reduction of quantitative and qualitative losses of mineral resources;

4. minimum distances of transportation of temporarily substandard raw materials and associated minerals during the storage and development of the man-made deposits.

However, these selective storage technologies provide the opening of the deposit after its filling by the passage of the surface trenches. Fundamentally different from the schemes described above, but in accordance with the above mentioned principles, the technology of formation of the man-made deposits with the system of tunnels and ore chutes, described in the works [8]. The described technology involves the discovery of the man-made deposit as an object of development, still in the formation stage. So, during the filling of the manmade deposit, the cargo transport connection of every stage with the surface of the bottom of the man-made deposit is secured by laying the fixing of horizontal and vertical workings. The developed technology allows to reduce the cost of development of the man-made deposit and to increase the completeness of mineral output by simplifying the access of extractive equipment to the mineral. Despite this, this technology has several disadvantages:

1. The formation and development of the man-made deposit in this way involves significant capital expenditures during the construction phase. At the same time, $17 \%$ of them are the cost of laying the fixing system, which is explained by the complexity of the installation work and the high cost of the materials, which were used.

2. Fixing, that is in the thickness of the man-made deposit, especially horizontal tunnels, require periodic metrological control, because they are in a constantly tense state.

3. The installation of the vertical timbering system requires only a bulldozer peripheral method of dumping. It is characterized by almost uniform distribution of oversize over the series of the man-made deposit. It brings the next problem. 
4. In this technological scheme with the placement of vibratory feeders at the bottom of the vertical workings, there is the probability of the backing with the oversize. Therefore, the proposed flow chart requires a uniform granularity without oversize. The technology proposed in [9] is devoid of these problems. According to it, the formation of the man-made deposit is performed by known storage technologies, and the types of minerals can be separated in plan and according to the height. After the release of a certain bank of the manmade deposit on the design boundary or complete filling of the manmade deposit, the ore chute can be formed on it in the form of an open trough.

Depending on the design capacity, the size of the man-made deposit and the angle of inclination of the bank, the open ore chute can be mobile or stationary. The stationary ore chute is placed in the inclined trench. The mobile ore chute is mounted on supports, which are on the bank of the man-made deposit. To reduce of an angle of the open ore chute, its surface may be lined with steel or other materials. At the bottom of the ore chute a hopper-loader with a vibrating feeder is placed. The method of the man-made deposit development is in the removing from the face of the necessary grade of mineral by the wheel loader and delivering it to the storage capacity at the mouth of the ore chute. From there, over the open ore chute, the man-made raw materials are transferred to the vibrating feeder under the action of gravity and bypassed to the rail or conveyor vehicles, located along the horizon of the daylight surface.

\section{Determination of the main parameters of the man-made de- posits}

The basic parameters of the man-made deposit include the size of the base, the number of stages, the angle of inclination of the bank, the capacity and production capacity of the man-made deposit. The angle of inclination of the bank will depend on the physical and mechanical properties of the rocks, the number of the stages - on the angle of inclination and the size of the basis of the man-made deposit. The capacity and production capacity of the man-made deposit must also be in a specific interdependence.

Minimum of specific costs for the formation and development of the man-made deposit was adopted as the criterion for assessing the efficiency of formation and development of the studied man-made 
deposits. It is revealed that the capacity of the man-made deposit influences the specific cost of its formation and development. Thus, as the volume of the man-made deposit increases, the specific costs of its exploration decrease, while the specific costs of the formation of the man-made deposit increase. This is explained by the increase in the distance of the overburden transportation during the dumping, which depends on the number of stages in the man-made deposit (fig. 1).

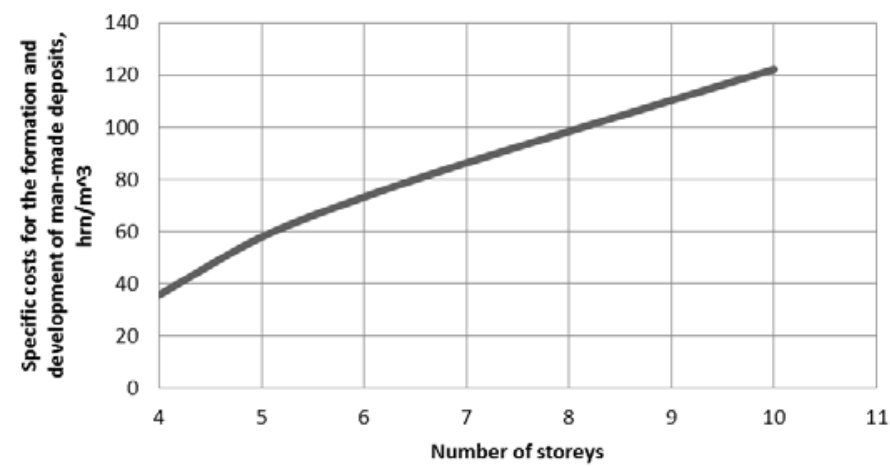

Fig. 1. The specific costs for the formation and development of the man-made deposit from the number of stages dependence diagram

In addition, it was found that the cost of forming and development of the man-made deposit is also affected by the range of transportation of dry mineral raw materials through the man-made deposit. This is due to the fact that with increasing the length of the basis of the man-made deposit increases the haulage of man-made raw materials to the open ore chute and accordingly reduces the annual operational productivity of the pneumatic wheel loader.

The distance of transportation of man-made raw materials through the man-made deposit is calculated as the average weighted distance from the ore chute to the rational limit of the transportation distance by a pneumatic wheel loader of $500 \mathrm{~m}$. This points to the necessity of choice of a rational mechanization complex to develop the man-made deposit. In turn, the cost of the complex will directly affect the cost of formation and development of the man-made deposit as a whole.

In the course of investigations the simultaneous influence of the capacitance of the man-made deposit and production capacity during 
its development on the cost of forming and development of the manmade deposit was identified. At the same time, it is obvious that the production capacity of the man-made deposit depends on its capacitance.

Therefore, it was decided to investigate the cumulative impact of these factors on final cost. For this purpose two cases were considered: at a fixed capacitance of the man-made deposit; at a constant production capacity.

It should be noted that the criterion for the choice of technological complex was the equipment utilization ratio, which should remain constant for both cases, which ensures the objectivity of cost comparison for both cases.

\section{Research of production capacity of the man-made deposit}

For research of the first case, the man-made deposit with a square base shape with a capacitance of $16473456 \mathrm{~m} 3$ was considered. It is clear that with the constant capacitance of the man-made deposit, its production capacity will vary depending on the period of development of the man-made deposit.

In order to ensure the rational use of technological equipment (maximize the utilization ratio), a rational mechanization complex was selected in the course of the research to develop the man-made deposit by a complex being a part of a pneumatic wheel loader and a vibrating feeder.

It is established that with different productivity of the man-made deposit, the capital and operating costs for its development, namely depreciation and costs for ongoing repair and maintenance of equipment, depending on the models of the loader and the vibrating feeder, will change.

The results of the research were presented in the form of a diagram (Fig. 2), which shows that with the increase of the working life and, consequently, the decrease in the productivity of the man-made deposit, the specific costs of its formation and development increase. 


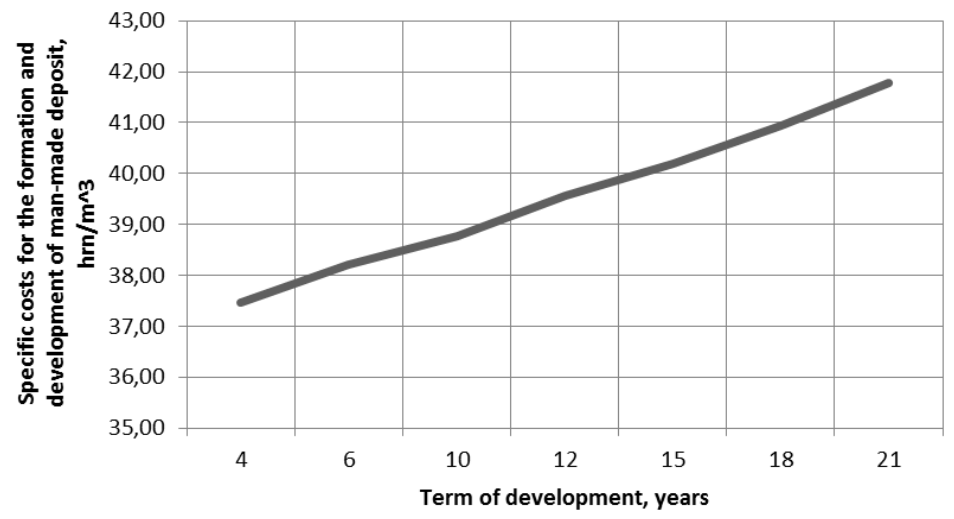

Fig. 2. The dependence diagram of specific costs for the formation and development of the man-made deposit at its production capacity at a fixed capacitance

\section{Investigation of the capacitance of the man-made deposit}

For the second case, a constant production capacity for each of the studied man-made deposits at the level of $18200000 \mathrm{~m}^{3} /$ year was adopted. Accordingly, with constant productivity of the man-made deposit, the term of its development depends on the capacitance.

Proceeding that the production capacity for each of the man-made deposits under study is constant at different capacitances, the following complex of technological equipment was selected for their development: one loader CAT988K with a capacity of $2862720 \mathrm{~m}^{3} /$ year and one vibration feeder ПЕВ 2 A- $4 * 15$ with productivity 2044800 $\mathrm{m}^{3} /$ year.

It is established that the cost of forming and development of the man-made deposit with a given productivity will also be affected by operating costs for its development, namely consumables in contrast to the case described above. The obtained results are presented in the form of a diagram (Fig. 3), which shows that with increasing the capacity of the man-made deposit and, accordingly, the period of its development, the specific costs for the formation and development of the man-made deposit are increasing. 


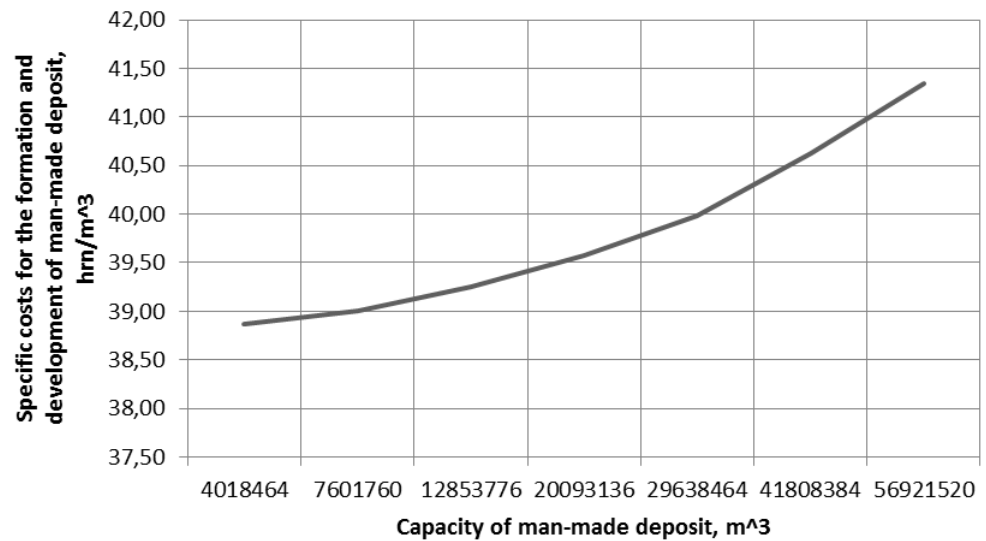

Fig. 3. The dependence diagram of specific costs for the formation and development of the man-made deposit with different capacity at its constant production capacitance

\section{Development of mathematical model of the main parameters}

The obtained results allowed us to compile an array of data for the permanent capacitances and production capacity of the man-made deposit and to investigate the cumulative influence of these parameters on the cost of formation and development of the man-made deposit.

For this purpose, a least square regression analysis for a twoargument function was performed, changed to the canonical form, a constraint system was added, and mathematical model according to the formula (1) was constructed and visualized as a three-dimensional diagram (fig. 4).

$$
\begin{gathered}
C_{T P}^{\text {num }}=41,02+4,31 \times 10^{-8} \times V_{T P}-1,13 \times 10^{-6} \times A_{T P} \rightarrow \min \\
\left\{\begin{array}{l}
V_{T P}=\left[4 \times 10^{-6} ; 57 \times 10^{6}\right] \\
A_{T P}=\left[0,78 \times 10^{6} ; 4,12 \times 10^{6}\right]
\end{array} A_{T P}=\left[0,78 \times 10^{6} ; 4,12 \times 10^{6}\right]\right.
\end{gathered}
$$




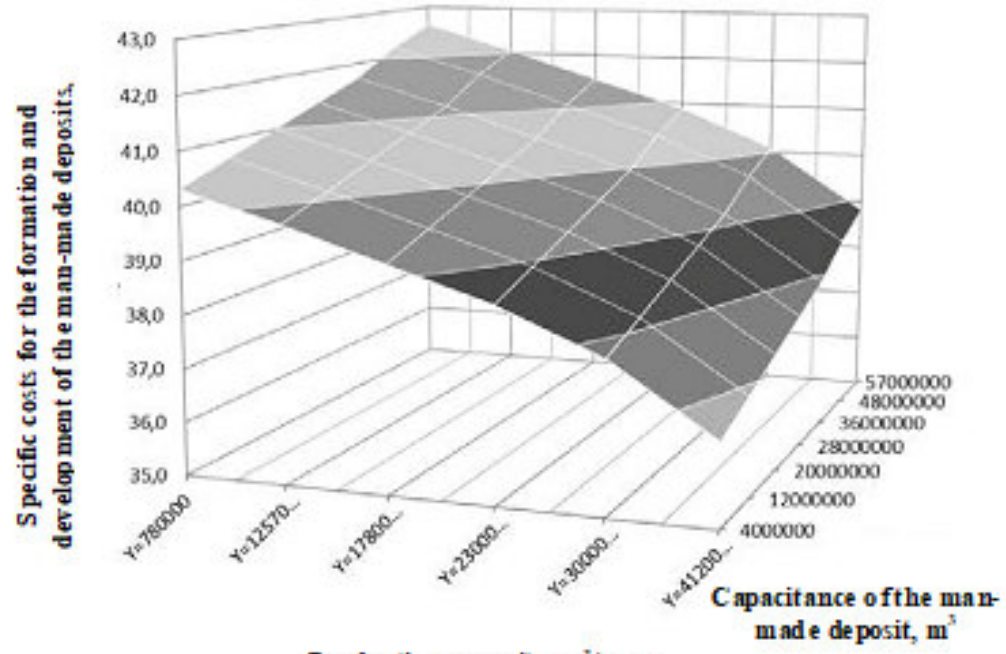

Production capacity, $\mathrm{m}^{3} /$ year

Fig.4. Cost of formation and development of the man-made deposit - its capacitance and production capacity three-dimensional interdependence diagram

The obtained mathematical model reflects the area of dependence of the cost of formation and development of the man-made deposit on its capacitance and production capacity, taking into account the interdependence of the latter.

\section{Conclusions and directions for further research.}

Thus, the main parameters of the man-made deposit were identified and their relationship was established. For the method of formation and development of the man-made deposit, investigated in the previous studies, the influence of capacitance and production capacity on the economic indicators of mining works was established. It is proved that the specific cost of formation and development of the man-made deposit are directly dependent on its capacitance and inverse - on the production capacity. At the same time, it was found that the capacitance of the man-made deposit has a greater influence on the specific cost of forming and development of the man-made deposit, than its production capacity. 
Further research will be directed to a detailed study of the relationship between the parameters of the elements of the development system of the man-made deposit for various technologies of its formation and development.

References

1. Kolesnikov D.V., Korolenko M.K., Stupnik N.I., Udod E.G., ProtasovV.P., Olejnik T.A. (2012). Povyshenie izvlecheniyazheleza za schyot pererabotki syry atekhnogennykh mestorozhdenij Krivbassa. KrivojRog: Dionis.

2. Trubeczkoj K.N., Umanecz V.N. (1992). Kompleksnoeosvoenie tekhnogennykh mestorozhdenij. Gornyjzhurnal - vyp. №1.

3. Temchenko A.G. (2000). Resursozberigayuchi` tekhnologiyi girnichogo virobnicztva. KryvyiRih: Mineral

4. Trubeczkoj K.N., Shapar` A.G. (1993). Malootkhodnye i resursosberegayushhie tekhnologii pri otkrytoj razrabotke mestorozhdenij. Moskva: Nedra.

5. Pshenichny j V.G. (2008). Czelesoobraznost stroitelstva i razrabotki tekhnogennykh mestorozhdenij mineralnogo syrya. Razrabotka rudnykh mestorozhdenij - vyp.№92.

6. Shapar`A.G., Krasnopolskij I.A., Kopach P.I. (1992). Resursosberezhenie $\mathrm{v}$ tekhnologicheskikh proczessakh otkrytoj razrabotki poleznykh iskopaemykh. Kiev: Naukova dumka.

7. Hryhoriev Y.I. (1992). Viznachennya osnovnikh metodichnikh princzipi`v czilenapravlenogo formuvannya tekhnogennikh rodovishh pri kompleksnomu osvoyenni` nadr. Girnichij visnik - vyp. 97.

8. Pyzhik N, GrigoryevY.(2015). Dryraw material technogenic deposits formation and development technique. Metallurgical and Mining Industry - № 3.

9. Hryhoriev I.J., Hryhoriev Y.I., Usachov V.E., Yevtushenko M.S. (2019). Viznachennya osnovnikh metodichnikh princzipiv czilenapravlenogo formuvannya tekhnogennikh rodovishh pri kompleksnomu osvoyenninadr. Zbirnik naukovikh pracz naczionalnogo girnichogo universitetu - vyp. 56

10. Trubeczkoj K.N., Vorobyov A.E. (1995). Osnovy resursovosproizvodyashhikh tekhnologij skladirovaniya i khraneniya nekondiczionnogo mineralnogo syrya. Gornyj zhurnal - vyp. №5

11. Hryhoriev I.J., Hryhoriev Y.I. (2011). Sistemnyj pokhod k proczessu proektirovaniya gornykh ob`ektov. Razrabotka rudnykh mestorozhdenij - vyp.№94. 